\title{
Northern Cordilleran terranes and their interactions through time
}

\begin{abstract}
Maurice Colpron*, Yukon Geological Survey, P.O. Box 2703 (K-10), Whitehorse, Yukon Y1A 2C6, Canada; JoAnne L. Nelson*, British Columbia Geological Survey, 1810 Blanshard Street, Victoria, British Columbia V8W 9N3, Canada; Donald C. Murphy*, Yukon Geological Survey, P.O. Box 2703 (K-10), Whitehorse, Yukon Y1A 2C6, Canada
\end{abstract}

\begin{abstract}
In the 25 years since the first application of the terrane concept to the North American Cordillera and the introduction of the term "suspect," a pattern of interterrane stratigraphic and intrusive linkages and shared isotopic and faunal elements has emerged. Far from being restricted to late, postamalgamation overlaps, these linkages can be as old as the oldest rocks within the terranes. In the Canadian Cordillera, these linkages give a coherent sense to terranes that otherwise might appear to be a collection of isolated and unrelated fragments. Such observed linkages effectively eliminate some of the paleogeographic uncertainties that were previously inferred between adjacent terranes (although not necessarily with respect to the Laurentian continent) and highlight their common history. In light of these relationships, it is now possible to interpret terranes of the Canadian Cordillera in terms of shared geodynamic scenarios, such as repeated arc superposition on older arcs and/or basement and coexisting arc system components. A primary result of this analysis is that the Intermontane terranes represent one interrelated set of arcs, marginal seas, and continental fragments that once formed a Paleozoic to early Mesozoic fringe to North America, the peri-Laurentian realm. By contrast, the Insular terranes, along with the Farewell and Arctic-Alaska terranes, include crustal fragments that originated from separate sites within the Arctic realm in Paleozoic time.
\end{abstract}

\section{INTRODUCTION}

The terrane concept was introduced some 25 years ago to describe the tectonically and stratigraphically composite nature of the North American Cordillera (Coney et al., 1980). Based upon knowledge of Cordilleran geology at that time, terranes were defined as fault-bounded crustal blocks that preserved a geological record distinct from that of adjacent terranes (Jones et al., 1983). Because of this inherent large-scale tectonostratigraphic granularity, the pre-accretionary paleogeographic positions of terranes with respect to each other and to the Laurentian craton were considered uncertain or, in the famous moniker, "suspect." The fundamental character of the Cordillera was envisaged as a collage (i.e., an assembly of diverse elements; Helwig, 1974; Coney et al., 1980). The terrane concept provided the underlying framework for much of the subsequent detailed mapping and tectonic analysis of the North American Cordillera. It has served to focus attention on relationships amongst terranes and has fostered the development and application of tools to resolve these relationships (e.g., $\mathrm{Nd}$ and Sr isotopes, detrital zircon geochronology, and paleomagnetism). These studies have significantly improved our understanding of the internal framework of the terranes and their external relationships (e.g., Monger and Nokleberg, 1996; Monger and Price, 2002). Extensive geochronological, isotopic, geochemical, fossil, paleomagnetic, and mineral deposit databases now allow for improved resolution of the geological history and geodynamic interpretation of many terranes, including genetic and/or evolutionary linkages between some terranes, and provide an improved framework for paleogeographic analysis.

Herein, we briefly summarize the current scientific understanding of northern Cordilleran terranes, particularly the Intermontane terranes and their interrelationships, and suggest updating the terrane concept in order to more accurately reflect this new understanding of the Cordilleran orogen. More exhaustive discussion of some of the relationships summarized here can be found in Nokleberg et al. (2000), Colpron and Nelson (2006), and Nelson and Colpron (2007).

\section{NORTHERN CORDILLERAN TERRANES}

Within the northern Cordillera, Proterozoic to Triassic miogeoclinal, mainly sedimentary, platformal to basinal strata of the western Laurentian continental margin (NAm and NAb on Fig. 1) extend into eastern British Columbia, Yukon, and eastcentral Alaska. Farther west, most of British Columbia, Yukon, and Alaska are made up of Paleozoic to Mesozoic volcanic, plutonic, sedimentary, and metamorphic assemblages that represent magmatic arcs, microcontinents, and ocean basins accreted to western Laurentia in Mesozoic and younger time. These, along with the parautochthonous deformed belt and the undisturbed platform of western Canada, are overlain by syn- and post-accretionary clastic deposits. The western and inner parts of the orogen are pierced by post-accretionary plutons and overlain in places by thick accumulations of relatively young volcanic strata.

Although the northern Cordillera has been subdivided into a multiplicity of terranes (cf. Coney et al., 1980; Wheeler et al., 1991; Fig. 1), it can be viewed more globally as consisting of five first-order tectonic entities (Fig. 1 inset):

1. Ancestral North America (Laurentia), including the YukonTanana upland, Alaska Range, and Kootenay terrane-the autochthon and parauthochthon;

2. The allochthonous marginal pericratonic terranes (Intermontane terranes)—-the peri-Laurentian realm;

*E-mails: maurice.colpron@gov.yk.ca; joanne.nelson@gov.bc.ca; don.murphy@gov.yk.ca

GSA Today: v. 17, no. 4/5, doi: 10.1130/GSAT01704-5A.1 


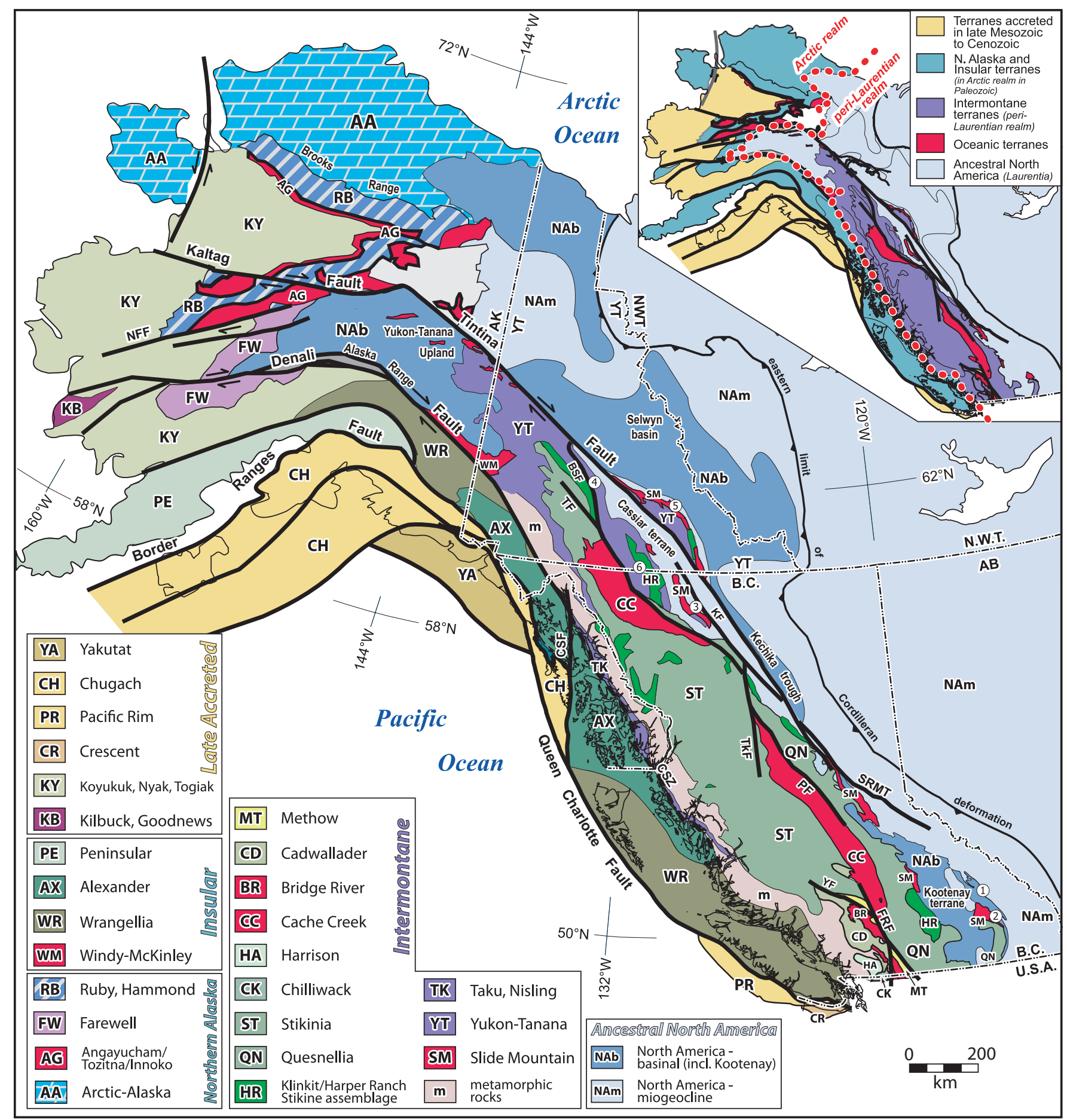

Figure 1. Terranes of the Canadian-Alaskan Cordillera. Inset shows terrane groupings and tectonic realms. Paleozoic basinal strata of Ancestral North America (NAb; e.g., Selwyn basin) were not previously included on terrane maps of the Cordillera (e.g., Wheeler et al., 1991). We include them here because they represent a first-order lithotectonic belt equivalent to many terranes and correlate with some of the displaced terranes (e.g., Kootenay terrane, Yukon-Tanana upland, and Northern Alaska Range). Numbers refer to locations where linkages exist amongst adjacent terranes (see text). Abbreviations for major post-accretionary faults: BSF_Big Salmon fault; CSF_Chatham Strait fault; CSZ_Coast shear zone; FRF_Fraser River fault; KF-Kechika fault; NFF-Nixon Fork-Iditarod fault; PF-Pinchi fault; SRMT_-southern Rocky Mountain trench; TkF-Takla-Finlay-Ingenika fault system; YK-Yalakom fault. Other abbreviations: AB-Alberta; AK—Alaska; B.C.—British Columbia; N.W.T.-Northwest Territories; YT—Yukon. Sources: Wheeler et al. (1991); Silberling et al. (1992); Colpron (2006). 
3. The Insular and Northern Alaska terranes, which evolved in the Arctic realm in Paleozoic time;

4. Oceanic and accretionary complex terranes, which evolved alongside the Intermontane and Northern Alaska-Insular terranes (shown in red on Fig. 1);

5. Mesozoic and younger arc and accretionary terranes that form a western and southern fringe to the older elements-the Late Accreted terranes in Figure 1.

Ancestral North America (Laurentia) includes the western craton margin, the miogeocline with its platforms and basins, and its fringing, parautochthonous terranes (Cassiar and Kootenay, Fig. 1). Until recently, metamorphic rocks of the YukonTanana upland and Alaska Range in east-central Alaska were considered a part of the allochthonous Yukon-Tanana terrane (see below); they are now interpreted as part of the parautochthonous Laurentian continental margin (see Dusel-Bacon et al., 2006; Nelson et al., 2006, for details). The western, outboard boundary of this autochthonous to parautochthonous belt is marked by discontinuous slivers and slices of the Slide Mountain oceanic terrane, which were formed in a marginal rift basin of Late Devonian to Permian age that once lay between the continent and a belt of rifted pericratonic fragments upon which successive Devonian through Jurassic arcs were formed (Yukon-Tanana, Quesnellia, Stikinia; Colpron et al., 2006; Nelson et al., 2006). The belt of pericratonic terranes was originally bounded on its outer, oceanward margin by an accretionary complex, the Cache Creek terrane, which includes slivers of high-pressure-low-temperature metamorphic assemblages, as well as blocks of limestone with exotic Permian fusulinid and coral faunas of Tethyan (Asian) affinity (Ross and Ross, 1983). Monger et al. (1982) defined the Intermontane superterrane as an amalgamation of many of the Intermontane terranes during Triassic-Jurassic accretion. In this discussion, we describe initial and ongoing relationships that span the entire period of the existence of these terranes. The position of the exotically derived Cache Creek terrane, enclosed within the pericratonic belt, is a constructional anomaly that may be best explained by oroclinal enclosure that developed as the Intermontane terranes amalgamated and accreted to the continent (Mihalynuk et al., 1994).

In fundamental contrast to the Intermontane terranes, the Insular terranes (Wrangellia and Alexander, Insular superterrane of Monger et al., 1982; and the Peninsular terrane of southwestern Alaska; Plafker et al., 1989) and the Farewell terrane of central Alaska (Bradley et al., 2003), although in part long-lived (Precambrian to Triassic) and in part of pericratonic origin, show no evidence of early relationships to the western margin of Laurentia. Instead, their early faunal and isotopic affinities are consistent with Siberia and Barentia (Bazard et al., 1995; Bradley et al., 2003; Nokleberg et al., 2000). The Arctic-Alaska terrane, although continental to pericratonic and thought to show continuity with the northernmost miogeocline (Lane, 1997), is anomalous with respect to western Laurentia (Patrick and McClelland, 1995). It bears stratigraphic similarities to the Chukotka peninsula of the Russian Far East; it has been proposed that Arctic-Alaska and Chukotka were contiguous throughout most of their histories and displaced and/or rotated into their current position in Cretaceous time (Miller et al., 2006). Together, the Insular, Farewell, and Arctic-Alaska terranes constitute an original set of mobile to detached crustal fragments, along with subsequent Paleozoic and Mesozoic arcs and basins, which developed mainly within the Arctic realm: They are collectively referred to here as the Northern AlaskaInsular terranes (Fig. 1, inset). Early in the history of Wrangellia, a Pennsylvanian pluton linked it to the Alexander terrane (Gardner et al., 1988). By Late Triassic to Early Jurassic time and prior to mid-Jurassic accretion with the Intermontane terranes, at least Wrangellia seems to have been transported to a more southerly paleolatitude west of the Laurentian margin (Aberhan, 1999; Smith et al., 2001). This set of terranes bounds the combined Laurentian margin and Intermontane (periLaurentian) terranes to the west (Fig. 1).

The outermost belt of terranes contains relatively young Mesozoic to Paleogene assemblages, including the accreted Yukon-Koyukuk arc, the Paleocene-Eocene seamounts of the Crescent terrane, and the Chugach, Pacific Rim, and Yakutat terranes, which are accretionary complexes dominated by trench sediments. These arc and accretionary assemblages developed within the eastern Pacific realm on or near the developing Cordilleran margin. Monger and Nokleberg (1996) interpreted them as paired accretionary prism-arc belts (see their work for a clear and useful synthesis).

\section{LINKING THE INTERMONTANE TERRANES}

In the southern Canadian Cordillera, the Kootenay and Slide Mountain terranes are stratigraphically linked to the Laurentian miogeocline. Lower Paleozoic, deep-water metasedimentary and metavolcanic rocks of the Lardeau Group (Kootenay terrane) are depositionally tied to Lower Cambrian carbonate and quartzite characteristic of the Laurentian miogeocline (1 on Figs. 1-2; Colpron and Price, 1995; Logan and Colpron, 2006). The Kootenay terrane is in turn stratigraphically and depositionally tied to the eastern side of the oceanic Slide Mountain terrane via strata of the Mississippian Milford Group, which unconformably overlies the Lardeau Group and, in an adjacent thrust panel, occurs stratigraphically below the Permian Kaslo Group (Slide Mountain; 2 on Figs. 1-2; Klepacki, 1985). Detrital zircon ages from sandstone of the Milford Group resemble those of the Lardeau Group and Neoproterozoic-Lower Cambrian miogeoclinal strata (Roback et al., 1994), suggesting a common source region and/or recycling of older units into younger ones. In northern British Columbia, clean quartz-chert sandstone beds interbedded with argillite and ribbon chert, and mafic volcanic strata in the Sylvester allochthon (Slide Mountain terrane; 3 on Fig. 1) have been correlated with coeval autochthonous siliciclastic units. These relationships suggest deposition near the Laurentian continental margin (Fig. 2). They mark the eastern margin of the Slide Mountain ocean, a marginal ocean basin that began to open in latest Devonian time and reached its maximum breadth in the Early Permian (Nelson et al., 2006).

In the northern Cordillera, the Yukon-Tanana terrane is inferred to have originated along the distal Laurentian continental margin and subsequently rifted away during the mid-Paleozoic opening of the Slide Mountain ocean (Fig. 3; Tempelman-Kluit, 1979; Nelson et al., 2006). The tectonostratigraphic base of the terrane (Snowcap assemblage) has geochemical, isotopic, and provenance characteristics pointing to a source along the northwestern Laurentian margin ( 4 on Figs. 


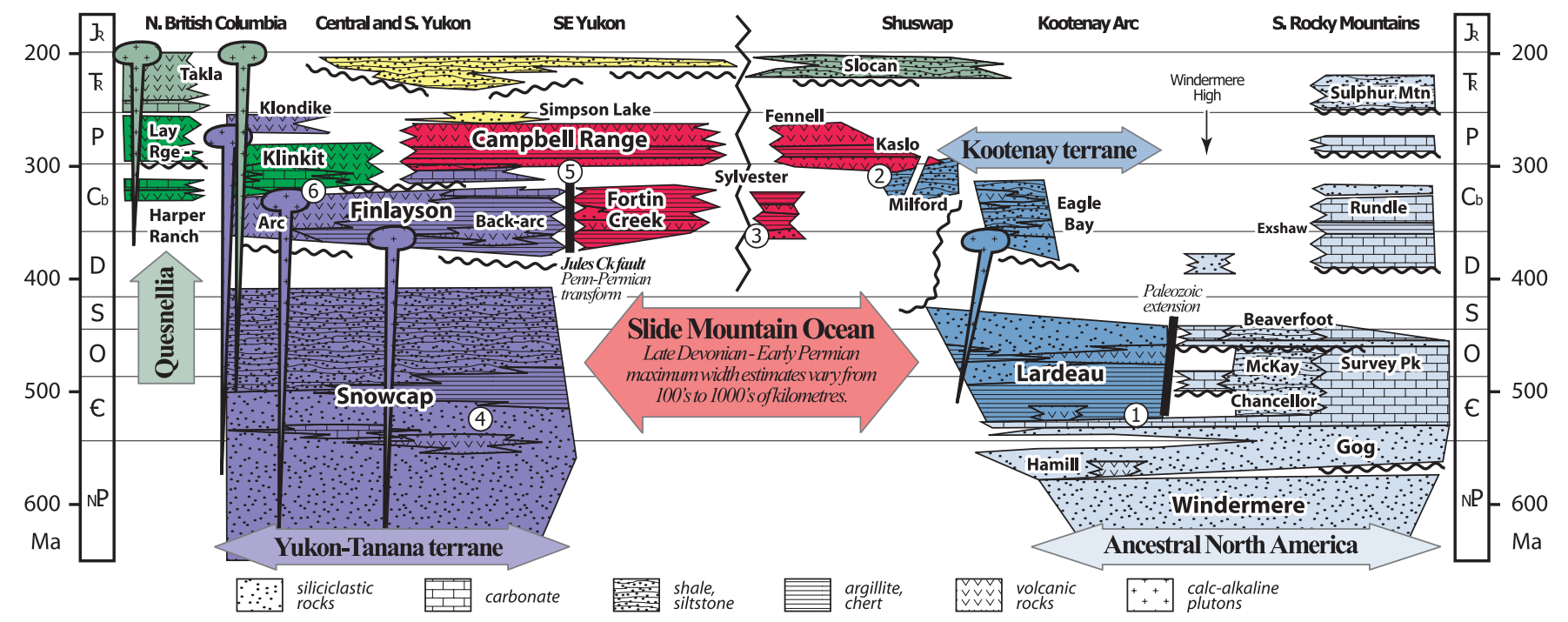

Figure 2. Schematic tectonostratigraphic relationships of the peri-Laurentian realm. The right-hand side of the diagram is constructed primarily from relationships in southeastern British Columbia (see text); the left-hand side is based on mapping of pericratonic terranes in northern British Columbia and Yukon. Numbers refer to linkages discussed in text and located on Figure 1. Only representative regional stratigraphic units are shown. Patterns illustrate dominant lithofacies; units are color-coded to terranes shown in Figure 1. Note the intricate boundaries amongst terranes of the peri-Laurentian realm. The demise of the Slide Mountain ocean began in Middle Permian time with subduction beneath the Yukon-Tanana terrane and is recorded by Permian eclogites in the Yukon-Tanana terrane, arc magmatism of the Klondike assemblage, and fore-arc deposits of the Simpson Lake Group. Triassic clastic rocks in Yukon (shown in yellow) overlap Yukon-Tanana, Slide Mountain, and North America.

1-2; Nelson et al., 2006) and forms the "nucleus" onto which Carboniferous to Permian magmatic arcs of the Yukon-Tanana terrane developed (Finlayson, Klinkit, and Klondike on Fig. 2). The Yukon-Tanana terrane shares Late Devonian to earliest Mississippian magmatism with the Laurentian margin, but younger Carboniferous to Permian magmatism is unique to the terrane.

Yukon-Tanana and Slide Mountain terranes are inferred to have evolved in adjacent geodynamic settings in mid- to late Paleozoic time. Arc magmatism in the Yukon-Tanana terrane is coeval with rift magmatism in the Slide Mountain terrane (Fig. 2); the presence of arc-derived detritus in the Carboniferous Fortin Creek group in the western part of the Slide Mountain terrane links the two into a Japanese arc-Sea of Japan-style convergent margin geodynamic setting (Fig. 3B). In southeastern Yukon, deposition of Lower Permian chert and basalt of Slide Mountain affinity (Campbell Range formation) onto Carboniferous "basements" of both Yukon-Tanana (Finlayson assemblage) and Slide Mountain affinities (Fortin Creek group) indicates that the Yukon-Tanana and Slide Mountain terranes have evolved together since at least Early Permian time (5 on Figs. 1-2; Murphy et al., 2006).

The relationship between the Yukon-Tanana and Slide Mountain terranes persisted into Late Permian time when subduction along the eastern margin of the Yukon-Tanana terrane led to the partial consumption of the Slide Mountain ocean. The Simpson Lake Group, a fore-arc basin conglomerate deposited on the Slide Mountain terrane, contains clasts of Upper Permian volcanic arc rocks akin to the Klondike assemblage of the Yukon-Tanana terrane and eclogite-facies metamorphic rocks with Late Permian cooling ages (Fig. 2; Murphy et al., 2006), showing linkages at that time.

The Yukon-Tanana terrane can be linked to Quesnellia as well. In the southern part of the Yukon-Tanana terrane, the
Late Mississippian to Early Permian Klinkit assemblage, which unconformably overlies Early Mississippian and older parts of the terrane (6 on Figs. 1-2; Colpron et al., 2006; Roots et al., 2006), has been correlated with the Lay Range stratigraphic succession of north-central British Columbia and the Harper Ranch Group of southern British Columbia on the basis of their similar stratigraphy, age, and geochemistry (Simard et al., 2003). Both the Lay Range and Harper Ranch are late Paleozoic arc-back-arc assemblages, which constitute the "basement" of the Mesozoic magmatic arc of Quesnellia and are an integral part of that terrane (Fig. 2). The Yukon-Tanana terrane is also intruded by a Late Triassic-Early Jurassic plutonic suite that it shares with Quesnellia and Stikinia (Nelson and Friedman, 2004).

The Late Permian consumption of the Slide Mountain ocean brought the remnants of the Intermontane terranes closer to the Laurentian continental margin. The approach of these terranes to the continental margin is recorded in Triassic strata deposited on both the Intermontane terranes and the Laurentian margin. In Yukon, Triassic siliciclastic rocks overlying the Laurentian miogeocline yielded detrital zircons characteristic of the Yukon-Tanana and Slide Mountain terranes (Beranek and Mortensen, 2007).

These relationships indicate that prior to their mid-Jurassic assembly, the major Intermontane terranes were not a set of unrelated, fault-bounded entities. Rather, they were interacting with each other as adjacent geodynamic elements in a complex and long-lived dance that spanned the entire history of some terranes. Relationships and boundaries between terranes evolved through time (Fig. 2). These, along with faunal and isotopic data, can be used to support reasonable inferences about the tectonic evolution of the western Laurentian margin sensu lato. We can, in this sense, now impose qualitative limits 

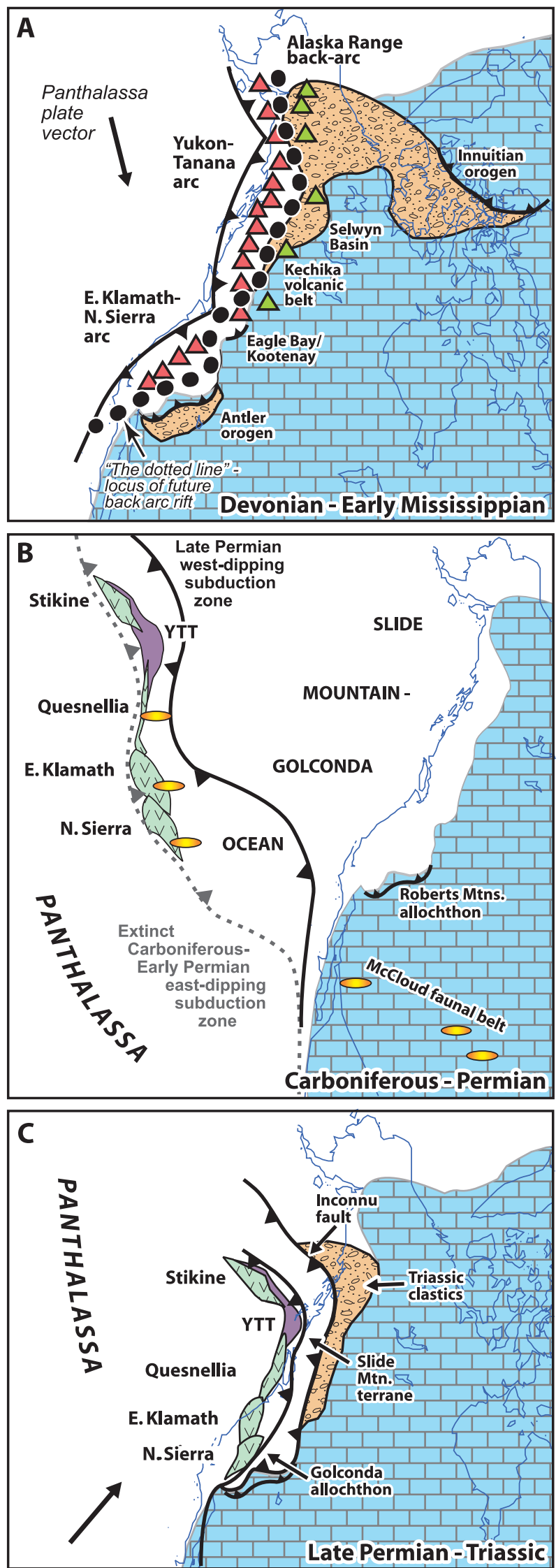

Figure 3. Mid-Paleozoic to early Mesozoic paleogeographic evolution of the peri-Laurentian realm. YTT-Yukon-Tanana terrane. on the degree of paleogeographic suspicion amongst the Intermontane terranes and, in some cases, between them and the Laurentian craton.

\section{DISCUSSION}

The relationships amongst the Intermontane terranes summarized here clearly suggest that these entities evolved together in the peri-Laurentian realm in mid- to late Paleozoic time as a set of offshore island arcs and continental fragments outboard of the Slide Mountain ocean basin that separated them from the Laurentian margin (Fig. 2; Rubin et al., 1990). These terranes were geodynamically linked, and each of them is characterized by the tectonostratigraphic record of one or more of the depositional environments that make up the complexity of convergent plate margins. Although many of these terranes are currently separated by faults, the majority of the faults are younger, post-accretionary features superposed on the terrane boundaries. Some of them likely nucleated along major crustal anisotropies and lateral facies changes that occur at the transitions between adjacent geodynamic environments (see also Helwig, 1974). Only a few appear to have originated at subduction zones and truly represent sutures between adjacent plates.

The interterrane connections and correlations discussed here do not mean that we have arrived at a neo-fixist interpretation of the Cordillera. For instance, Permian fossil assemblages characteristic of the McCloud faunal belt in rocks of the Intermontane terranes imply considerable mobility of these terranes with respect to the Laurentian margin. On the basis of faunal affinities, Belasky et al. (2002) proposed that they probably lay 2000-3000 km west of the Laurentian margin in Early Permian time. In our model of Cordilleran evolution (Fig. 3; Nelson et al., 2006), the Yukon-Tanana terrane (the underpinning of the Intermontane terranes) originated in northwestern Laurentia and migrated southward and westward as the Slide Mountain ocean opened in mid- to late Paleozoic time. Reversal of subduction polarity in the Middle Permian marked the onset of the demise of the Slide Mountain ocean. In the early Mesozoic, the Yukon-Tanana terrane, along with its juvenile arc cover (Harper Ranch, Quesnellia, and Stikinia), was rejoined to the Laurentian margin, apparently near its point of origin, as the Slide Mountain ocean closed. Large-scale translation of the Intermontane terranes indicated by the McCloud fauna was evidently mostly accommodated by relative plate motions and oblique subduction within the Slide Mountain ocean prior to their Jurassic accretion to North America.

Estimates of paleogeographic positions and origins of the Intermontane terranes are derived primarily from detrital zircon populations, isotopic compositions, and faunal assemblages (Nelson et al., 2006; Belasky et al., 2002). Although these methods provide imprecise pins (e.g., detrital zircons can travel long distances), they all consistently show ties to the Laurentian craton. In the case of the Yukon-Tanana terrane, the predominance of Paleoproterozoic and Archean detrital zircons, Nd-Hf-Pb isotopic data, and Late Devonian magmatic and metallogenetic histories point more specifically to a source in northwestern Laurentia (off Selwyn basin or the Kootenay terrane). 
Post-accretion northward translation of the Intermontane terranes by dextral strike-slip faults, mainly in Cretaceous and younger times, is geologically constrained to be on the order of $860 \mathrm{~km}$ (Gabrielse et al., 2006), considerably less than the $2000+\mathrm{km}$ indicated by paleomagnetic data from Late Cretaceous rocks (Irving et al., 1996). Although a full discussion of this enduring conundrum of Cordilleran geology is beyond the scope of this paper, it is important to note that it has recently been recast from an intra-Cordilleran problem to one that now encompasses the entire northern Cordillera (see Enkin, 2006, for a review). Originally, anomalously shallow paleomagnetic inclinations from the Insular terranes were interpreted to require large latitudinal displacements on intra-Cordilleran faults, such as the Coast shear zone (CSZ on Fig. 1; Irving et al., 1996). More recently, shallow paleomagnetic inclinations have been measured at more inboard sites along the eastern edge of the Intermontane terranes and in the southern Rocky Mountains (Enkin, 2006), such that northward, large-scale translation of the entire northern Cordillera is now indicateda concept that is difficult to reconcile with the well-established geological framework of the foreland fold-and-thrust belt. Butler et al. (2001) offered a moderate translation alternative $(\sim 1000 \mathrm{~km})$, which is more in line with geological constraints and accounts for the shallow paleomagnetic inclinations in part by tilting and compaction shallowing. Regardless of how this debate is ultimately resolved, in its present incarnation, it does not affect the internal configuration and relationships of the Intermontane terranes-only the latitudinal position of the entire northern Cordillera!

\section{CONCLUSIONS}

Cordilleran terranes are defined on the basis of their distinct tectonostratigraphic records, but they are not necessarily limited to fault-bounded crustal blocks. The pattern of interrelatedness summarized here for the Intermontane terranes of the Canadian Cordillera shows that adjacent terranes can locally share depositional and geodynamic ties and that the nature of terrane boundaries evolves through time. This emerging picture confirms the value of inferences about the geodynamic setting(s) of terranes and their potential for linkages with neighboring terranes as an integral part of terrane analysis.

\section{ACKNOWLEDGMENTS}

Discussions with many of our Cordilleran colleagues, in particular John Bradford, Cynthia Dusel-Bacon, Fil Ferri, Hu Gabrielse, George Gehrels, Warren Hamilton, Mitch Mihalynuk, Jim Monger, Jim Mortensen, Steve Piercey, and Jim Ryan, have influenced our thoughts on Cordilleran terranes, although their endorsement of our interpretations is not implied. Comments by Diane Emond, Anna Fonseca, and Lee Pigage on an early version of the manuscript helped improve its presentation and clarity. This paper also benefited from reviews by Cynthia Dusel-Bacon, George Gehrels, Gerry Ross, and an anonymous reader.

\section{REFERENCES CITED}

Aberhan, M., 1999, Terrane history of the Canadian Cordillera: Estimating amounts of latitudinal displacement and rotation of Wrangellia and Stikinia: Geological Magazine, v. 136, p. 481-492, doi: 10.1017/S001675689900299X.

Bazard, D.R., Butler, R.F., Gehrels, G.E., and Soja, C.M., 1995, Early Devonian paleomagnetic data from the Lower Devonian Karheen Formation suggest LaurentiaBaltica connection for the Alexander terrane: Geology, v. 23, p. 707-710, doi: 10.1130/0091-7613(1995)023<0707:EDPDFT>2.3.CO;2.
Belasky, P., Stevens, C.H., and Hanger, R.A., 2002, Early Permian location of western North American terranes based on brachiopod, fusulinid and coral biogeography: Palaeogeography, Palaeoclimatology, Palaeoecology, v. 179, p. 245-266, doi: 10.1016/S0031-0182(01)00437-0.

Beranek, L.P., and Mortensen, J.K., 2007, Investigating a Triassic overlap assemblage in Yukon: On-going field studies and preliminary detrital-zircon age data, in Emond, D.S., Lewis, L.L., and Weston, L.H., eds., Yukon Exploration and Geology 2006: Yukon Geological Survey, p. 83-92.

Bradley, D.C., Dumoulin, J., Layer, P., Sunderlin, D., Roeske, S., McClelland, W. Harris, A.G., Abbott, G., Bundtzen, T., and Kusky, T., 2003, Late Paleozoic orogeny in Alaska's Farewell terrane: Tectonophysics, v. 372, p. 23-40, doi: 10.1016/S0040-1951(03)00238-5.

Butler, R.F., Gehrels, G.E., and Kodama, K.P., 2001, A moderate translation alternative to the Baja British Columbia hypothesis: GSA Today, v. 11, no. 6, p. 4-10, doi: 10.1130/1052-5173(2001)011<0004:AMTATT>2.0.CO;2.

Colpron, M., 2006, Tectonic assemblage map of Yukon-Tanana and related terranes in Yukon and northern British Columbia: Yukon Geological Survey, Open File 2006-1, scale 1:1,000,000.

Colpron, M., and Nelson, J.L., editors, 2006, Paleozoic evolution and metallogeny of pericratonic terranes at the ancient Pacific margin of North America, Canadian and Alaskan Cordillera: Geological Association of Canada Special Paper 45, 523 p.

Colpron, M., and Price, R.A., 1995, Tectonic significance of the Kootenay terrane, southeastern Canadian Cordillera: An alternative model: Geology, v. 23, p. 2528, doi: 10.1130/0091-7613(1995)023<0025:TSOTKT>2.3.CO;2.

Colpron, M., Nelson, J.L., and Murphy, D.C., 2006, A tectonostratigraphic framework for the pericratonic terranes of the northern Cordillera, in Colpron, M., and Nelson, J.L., eds., Paleozoic Evolution and Metallogeny of Pericratonic Terranes at the Ancient Pacific Margin of North America, Canadian and Alaskan Cordillera: Geological Association of Canada Special Paper 45, p. 1-23.

Coney, P.J., Jones, D.L., and Monger, J.W.H., 1980, Cordilleran suspect terranes: Nature, v. 288, p. 329-333, doi: 10.1038/288329a0.

Dusel-Bacon, C., Hopkins, M.J., Mortensen, J.K., Dashevsky, S.S., Bressler, J.R., and Day, W.C., 2006, Paleozoic tectonic and metallogenic evolution of the pericratonic rocks of east-central Alaska and adjacent Yukon, in Colpron, M., and Nelson, J.L., eds., Paleozoic Evolution and Metallogeny of Pericratonic Terranes at the Ancient Pacific Margin of North America, Canadian and Alaskan Cordillera: Geological Association of Canada Special Paper 45, p. 25-74.

Enkin, R.J., 2006, Paleomagnetism and the case for Baja British Columbia, in Haggart, J.W., Monger, J.W.H., and Enkin, R.J., eds., Paleogeography of the North American Cordillera: Evidence for and against Large-Scale Displacements: Geological Association of Canada Special Paper 46, p. 233-253.

Gabrielse, H. Murphy, D.C., and Mortensen, J.K., 2006, Cretaceous and Cenozoic dextral orogen-parallel displacements, magmatism and paleogeography, northcentral Canadian Cordillera, in Haggart, J.W., Monger, J.W.H., and Enkin, R.J., eds., Paleogeography of the North American Cordillera: Evidence for and against Large-Scale Displacements: Geological Association of Canada Special Paper 46, p. 255-276.

Gardner, M.C., Bergman, S.C., Cushing, G.W., MacKevett, E.M.J., Plafker, G. Campbell, R.B., Dodds, C.J., McClelland, W.C., and Mueller, P.A., 1988, Pennsylvanian pluton stitching of Wrangellia and the Alexander terrane, Wrangell Mountains, Alaska: Geology, v. 16, p. 967-971, doi: 10.1130/00917613(1988)016<0967:PPSOWA >2.3.CO;2.

Helwig, J., 1974, Eugeosynclinal basement and a collage concept of orogenic belts, in Dott, R.H., Jr., and Shaver, R.H., eds., Modern and ancient geosynclinal sedimentation: Society of Economic Paleontologists and Mineralogists Special Publication 19, p. 359-380.

Irving, E., Wynne, P.J., Thorkelson, D.J., and Schiarizza, P., 1996, Large (1000 to 4000 $\mathrm{km})$ northward movements of tectonic domains in the northern Cordillera, 83 to $45 \mathrm{Ma}$ : Journal of Geophysical Research, v. 101, no. B8, p. 17,901-17,916, doi: 10.1029/96JB01181.

Jones, D.L., Howell, D.G., Coney, P.J., and Monger, J.W.H., 1983, Recognition, character and analysis of tectono-stratigraphic terranes in western North America, in Hashimoto, M., and Uyeda, S., eds., Accretion Tectonics in the Circum-Pacific Region: Terra, Tokyo, p. 21-35.

Klepacki, D.W., 1985, Stratigraphy and structural geology of the Goat Range area southeastern British Columbia [Ph.D. thesis]: Massachusetts Institute of Technology, $268 \mathrm{p}$.

Lane, L.S., 1997, Canada Basin, Arctic Ocean: Evidence against a rotational origin: Tectonics, v. 16, p. 363-387, doi: 10.1029/97TC00432.

Logan, J.M., and Colpron, M., 2006, Stratigraphy, geochemistry, syngenetic sulphide occurrences and tectonic setting of the lower Paleozoic Lardeau Group, northern Selkirk Mountains, British Columbia, in Colpron, M., and Nelson, J.L., eds., Paleozoic Evolution and Metallogeny of Pericratonic Terranes at the Ancient Pacific Margin of North America, Canadian and Alaskan Cordillera: Geological Association of Canada Special Paper 45, p. 361-382.

Mihalynuk, M.G., Nelson, J., and Diakow, L.J., 1994, Cache Creek terrane entrapment: Oroclinal paradox within the Canadian Cordillera: Tectonics, v. 13, p. 575-595, doi: 10.1029/93TC03492.

Miller, E.L., Toro, J., Gehrels, G.E., Amato, J.M., Prokopiev, A., Tuchkova, M.I., Akinin, V.V., Dumitru, T.A., Moore, T.E., and Cecile, M.P., 2006, New insights into Arctic paleogeography and tectonics from $\mathrm{U}-\mathrm{Pb}$ detrital zircon geochronology: Tectonics, v. 25, TC3013, p. 1-19.

Monger, J.W.H., and Nokleberg, W.J., 1996, Evolution of the northern North American 
Cordillera: Generation, fragmentation, displacement and accretion of successive North American plate-margin arcs, in Coyner, A.R., and Fahey, P.L., eds. Geology and Ore Deposits of the American Cordillera: Geological Society of Nevada Symposium Proceedings, v. III, p. 1133-1152.

Monger, J.W.H., and Price, R.A., 2002, The Canadian Cordillera: Geology and tectonic evolution: Canadian Society of Exploration Geophysicists Recorder, v. 27, p. $17-36$.

Monger, J.W.H., Price, R.A., and Tempelman-Kluit, D.J., 1982, Tectonic accretion and the origin of two metamorphic and plutonic welts in the Canadian Cordillera: Geology, v. 10, p. 70-75, doi: 10.1130/0091-7613(1982)10<70: TAATOO $>2$ 2.0.CO; 2

Murphy, D.C., Mortensen, J.K., Piercey, S.J., Orchard, M.J., and Gehrels, G.E., 2006 , Mid-Paleozoic to early Mesozoic tectonostratigraphic evolution of YukonTanana and Slide Mountain terranes and affiliated overlap assemblages, Finlayson Lake massive sulphide district, southeastern Yukon, in Colpron, M and Nelson, J.L., eds., Paleozoic Evolution and Metallogeny of Pericratonic Terranes at the Ancient Pacific Margin of North America, Canadian and Alaskan Cordillera: Geological Association of Canada Special Paper 45, p. 75-105.

Nelson, J.L., and Colpron, M., 2007, Tectonics and metallogeny of the Canadian and Alaskan Cordillera, 1.8 Ga to present, in Goodfellow, W., ed., Mineral Deposits of Canada: A Synthesis of Major Deposit Types, District Metallogeny, the Evolution of Geological Provinces, and Exploration Methods: Geological Association of Canada, Mineral Deposit Division, Special Publication, in press.

Nelson, J.L., and Friedman, R.M., 2004, Superimposed Quesnel (late PaleozoicJurassic) and Yukon-Tanana (Devonian-Mississippian) arc assemblages, Cassiar Mountains, northern British Columbia: Field, U-Pb and igneous petrochemical evidence: Canadian Journal of Earth Sciences, v. 41, p. 1201-1235, doi: 10.1139/e04-028.

Nelson, J.L., Colpron, M. Piercey, S. J, Dusel-Bacon, C, Murphy, D.C., and Roots, C.F., 2006, Paleozoic tectonic and metallogenic evolution of the pericratonic terranes in Yukon, northern British Columbia and eastern Alaska, in Colpron M., and Nelson, J.L., eds., Paleozoic Evolution and Metallogeny of Pericratonic Terranes at the Ancient Pacific Margin of North America, Canadian and Alaskan Cordillera: Geological Association of Canada Special Paper 45, p. 323-360.

Nokleberg, W.J., Parfenov, L.M., Monger, J.W.H., Norton, I.O., Khanchuk, A.I., Stone D.B., Scotese, C.R., Scholl, D.W., and Fujita, K., 2000, Phanerozoic tectonic evolution of the circum-North Pacific: U.S. Geological Survey Professional Paper $1626,122 \mathrm{p}$

Patrick, B.E., and McClelland, W.C., 1995, Late Proterozoic granitic magmatism on Seward Peninsula and a Barentian origin for Arctic Alaska-Chukotka: Geology, v. 23, p. 81-84, doi: 10.1130/0091-7613(1995)023<0081: LPGMOS $>2.3 . C O ; 2$

Plafker, G., Nokleberg, W.J., and Lull, J.S., 1989, Bedrock geology and tectonic evolution of the Wrangellia, Peninsular and Chugach terranes along the Trans-Alaska crustal transect in the Chugach Mountains and southern Copper River Basin, Alaska: Journal of Geophysical Research, v. 94, B4, p. 4255-4295.

Roback, R.C., Sevigny, J.H., and Walker, N.W., 1994, Tectonic setting of the Slide Mountain terrane, southern British Columbia: Tectonics, v. 13, p. 1242-1258, doi: 10.1029/94TC01032.

Roots, C.F, Nelson, J.L., Simard, R.-L, and Harms, T.A., 2006, Continental fragments, mid-Paleozoic arcs and overlapping late Paleozoic arc and Triassic sedimentary strata in the Yukon-Tanana terrane of northern British Columbia and southern Yukon, in Colpron, M., and Nelson, J.L., eds., Paleozoic Evolution and Metallogeny of Pericratonic Terranes at the Ancient Pacific Margin of North America, Canadian and Alaskan Cordillera: Geological Association of Canada Special Paper 45, p. 153-177.

Ross, C.A., and Ross, J.R.P., 1983, Late Paleozoic accreted terranes of western North America, in Stevens, C.H., ed., Pre-Jurassic rocks in western North American suspect terranes: Pacific Section, Society of Economic Paleontologists and Mineralogists, p. 7-22.

Rubin, C.M., Miller, M.M., and Smith, G.M., 1990, Tectonic development of Cordilleran mid-Paleozoic volcano-plutonic complexes; Evidence for convergent margin tectonism, in Harwood, D.S., and Miller, M.M., eds., Paleozoic and early Mesozoic paleogeographic relations; Sierra Nevada, Klamath Mountains, and related terranes: Geological Society of America Special Paper 255 , p. $1-16$

Silberling, N.J., Jones, D.L., Monger, J.W.H., and Coney, P.J., 1992, Lithotectonic terrane map of the North American Cordillera: U.S. Geological Survey Miscellaneous Investigation Map I-2176, scale 1:5,000,000.

Simard, R.-L., Dostal, J., and Roots, C.F., 2003, Development of late Paleozoic volcanic arcs in the Canadian Cordillera: an example from the Klinkit Group, northern British Columbia and southern Yukon: Canadian Journal of Earth Sciences, v. 40, p. 907-924, doi: 10.1139/e03-025.

Smith, P.L., Tipper, H.W., and Ham, D.M., 2001, Lower Jurassic Amaltheidae (Ammotina) in North America: Paleobiogeography and tectonic implications: Canadian Journal of Earth Sciences, v. 38, p. 1439-1449, doi: 10.1139/cjes38-10-1439.

Tempelman-Kluit, D.J., 1979, Transported cataclasite, ophiolite and granodiorite in Yukon: evidence of arc-continent collision: Geological Survey of Canada Paper 79-14, 27 p.

Wheeler, J. Brookfield, A.J., Gabrielse, $\mathrm{H}$, Monger, JW. H., Tipper, H.W, and Woodsworth, G.J., 1991, Terrane map of the Canadian Cordillera: Geological Survey of Canada, Map 1713A, scale 1:2,000,000.

Manuscript received 21 November 2006; accepted 5 February 2007. o:

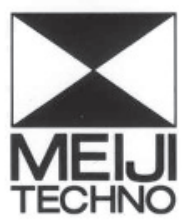

政
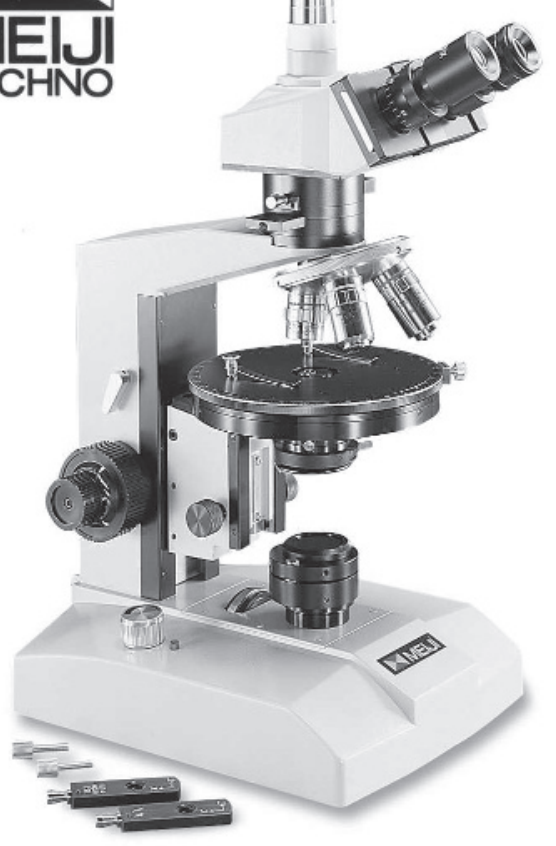

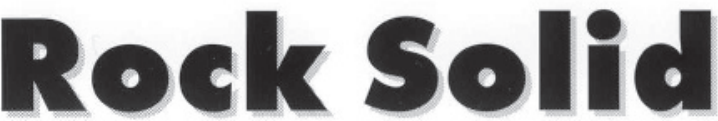

Meiji ML Series

Polarizing Microscopes

Solid as a rock and crystal clear is what you will find when you look into these Polarizing Microscopes.

Each ML 9000 Series Microscope is equipped with swing-in, swing-out polarizer, analyzer and Bertrand lens for extra-bright, extra large interface figures. Every package includes DIN standard compensators (Mica 1/4 wave plate and first order red plate), strain free optics and a $360^{\circ}$ graduated rotatable stage. You have a choice of 3 bodies - monocular, binocular or trinocular and a full range of accessories to create the ideal instrument for your specific needs and Meiji stands behind every instrument with its "Limited Lifetime Warranty."

For more information on these economically priced Microscopes, please call, FAX, write us or log on to our website today.

\section{MEIJI TECHNO AMERICA} 3010 Olcott Street, Santa Clara, CA 95054-3027

Toll Free Telephone: 800.832 .0060 or visit our website at www.meijitechno.com 